\title{
An improved culture medium supports development of random-bred 1-cell mouse embryos in vitro
}

\author{
C. L. Chatot, C. A. Ziomek, B. D. Bavister*, J. L. Lewis and I. Torres \\ Worcester Foundation for Experimental Biology, 222 Maple Avenue, Shrewsbury, MA 01545, USA; \\ and ${ }^{*}$ Department of Veterinary Science, University of Wisconsin, Madison, WI 53706, USA
}

\begin{abstract}
Summary. One-cell CF-1 $\times \mathrm{B}_{6} \mathrm{SJLF}_{1} / \mathrm{J}$ embryos, which usually exhibit a 2-cell block to development in vitro, have been cultured to the blastocyst stage using CZB medium and a glucose washing procedure. CZB medium is a further modification of modified BMOC-2 containing an increased lactate/pyruvate ratio of $116,1 \mathrm{~mm}$-glutamine and 0.1 mM-EDTA but lacking glucose. Continuous culture of one-cell embryos in CZB medium allowed $83 \%$ of embryos to develop beyond the 2-cell stage of which $63 \%$ were morulae at $72 \mathrm{~h}$ of culture, but blastocysts did not develop. However, washing embryos into CZB medium containing glucose after $48 \mathrm{~h}$ of culture (3-4-cell stage) was sufficient to allow development to proceed, with $48 \%$ of embryos reaching the blastocyst stage by $96 \mathrm{~h}$ of culture. Exposure of embryos to glucose was only necessary from the 3-4-cell stage through the early morula stage since washing back into medium CZB without glucose at $72 \mathrm{~h}$ of culture still promoted the development of $50 \%$ of embryos to the blastocyst stage. The presence of glucose in this medium for the first $48 \mathrm{~h}$ of culture (1-cell to 4-cell stage) was detrimental to embryo development. Glutamine, however, exerted a beneficial effect on embryo development from the 1-cell to the 4-cell stage although its presence was not required for development to proceed during the final $48 \mathrm{~h}$ of culture. Blastocysts which developed under optimum conditions contained an average of 33.7 total cells. The in-vitro development of 1-cell embryos beyond the 2-cell stage in response to the removal of glucose and the addition of glutamine to the culture medium suggests that glucose may block some essential metabolic process, and that glutamine may be a preferred energy substrate during early development for these mouse embryos.
\end{abstract}

Keywords: mouse; embryo; 2-cell block; glutamine; glucose

\section{Introduction}

The culture of 2-cell mouse embryos to the blastocyst stage can now be performed with consistency in a variety of chemically defined media containing lactate alone (Whitten, 1957; Brinster, 1963) or lactate and pyruvate (Brinster, 1965a) as energy sources. These blastocysts are capable of implantation and fetal development upon transfer to recipient pseudopregnant females (Biggers et al., 1965).

The culture of 1-cell mouse embryos to the blastocyst stage has met with more limited success. With the exception of some inbred and F1 strains (Whitten \& Biggers, 1968; Kaufman \& Sachs, 1976; Goddard \& Pratt, 1983), 1-cell mouse embryos exhibit what has been termed a '2-cell block' to development in vitro, i.e. the 1-cell embryos undergo a single cleavage division in vitro and are arrested at the 2-cell stage. In experiments using reciprocal crosses between blocking and nonblocking strains, Goddard \& Pratt (1983) have demonstrated that this in-vitro 2-cell block is a maternally regulated phenomenon. By transferring cytoplasm from a non-blocking embryo to a 
blocking embryo, Muggleton-Harris et al. (1982) and Pratt \& Muggleton-Harris (1988) have shown that the block is mediated by a cytoplasmic component which may be lacking in embryos from blocking strains.

The ability of 1-cell mouse embryos to develop in vitro has been shown to be a function of mouse strain (Whitten \& Biggers, 1968; Kaufman \& Sachs, 1976; Abramczuk et al., 1977), medium components (Biggers et al., 1967; Whittingham \& Biggers, 1967; Cross \& Brinster, 1973; Abramczuk et al., 1977; Loutradis et al., 1987) and culture conditions (Quinn \& Harlow, 1978).

Two factors reported independently to be beneficial for culture of some blocking strains of embryos are: a lactate/pyruvate ratio approaching 120 (Cross \& Brinster, 1973) and the addition of EDTA to the culture medium (Abramczuk et al., 1977). However, there is considerable variation in the success of these culture modifications in different laboratories.

The mouse is not the only species which exhibits a block to development in vitro as hamster, rat and pig all exhibit a block to in-vitro development at various stages. For example, golden hamster embryos block in vitro at both the 2-and 4-cell stage and only $2 \%$ of 8 -cell embryos develop to blastocysts (Bavister et al., 1983). However, supplementation of the basic culture medium with a group of four amino acids increased the development of 8-cell hamster embryos to blastocysts to $36 \%$ (Bavister et al., 1983). Carney \& Bavister (1987) showed that, of the four amino acids in this culture medium, glutamine was the most efficient at improving development.

In this study we have attempted to develop a completely defined medium which will consistently allow culture of 1-cell embryos from mice which exhibit a block in vitro to the blastocyst stage. We have selected the CF-1 mouse for this study because it blocks at the 2-cell stage in all media tested in our laboratory although Dandekar \& Glass (1987) have reported the culture of CF-1 embryos to the blastocyst stage in a medium containing human serum. Furthermore, it is highly economic for scientists to use this CF-1 strain since it produces an average of $40-50$ embryos per female.

\section{Materials and Methods}

Embryo collection. CF-1 female mice (Harlan Sprague Dawley, Colony 202, Indianapolis, IN, USA) were superovulated with intraperitoneal injections of 10 i.u. PMSG (Calbiochem, La Jolla, CA, USA) followed $48 \mathrm{~h}$ later by 5 i.u. hCG (Organon, W. Orange, NJ, USA). Females were mated overnight with B6SJLF1/J males (an F1 hybrid from C57BL/6J $\times$ SJL/J: Jackson Laboratories, Bar Harbor, ME, USA). One-cell embryos were flushed from excised oviducts at $25-27 \mathrm{~h}$ after hCG (Day l) in Hank's balanced salt solution containing $4 \mathrm{mg}$ bovine serum albumin/ml (Cat. No. 0140, Armour Pharmaceutical Co. Kankakee, IL, USA) (HBSS + BSA).

When necessary, cumulus cells were removed from fertilized ova by hyaluronidase treatment $(300 \mathrm{units} / \mathrm{ml} \mathrm{in}$ phosphate-buffered saline (PBS) containing $1 \%$ polyvinylpyrrolidone; Sigma Chemical Co., St Louis, MO, USA) and embryos were then washed through three drops of HBSS + BSA. Embryos were placed in a holding dish containing $50 \mu \mathrm{l}$ drops of culture medium overlaid with Fisher 121 paraffin oil (Fisher, Medford, MA, USA) which was washed before use with two changes of complete CZB medium for $96 \mathrm{~h}$ with stirring $(10 \mathrm{ml}$ medium per $100 \mathrm{ml}$ oil). All collections were performed in a darkened room as Schumacher \& Fischer (1988) suggested that as little as $1 \mathrm{~h}$ of exposure to light is significantly harmful to Day-1 rabbit embryo development. All solutions, dishes and instruments were maintained at $37^{\circ} \mathrm{C}$ before use.

Culture media. Embryos were cultured in four basic media: a modified version of Whittingham's (1971) original Medium 16 (M16), modified Whitten's medium (WM) (Hoppe, 1985), modified Earle's BSS (EBSS) with EDTA (Dr Ann Kiessling, personal communication) and a modified BMOC-2 medium (Ebert \& Brinster, 1983) which has been further modified and designated CZB medium. Formulations for these media are shown in Table 1. Media variations were based on changes in these formulae. Glutamine was added to media from a fresh 100 mm-glutamine stock immediately before use. Medium was prepared on the basis of weight in T25 or T75 polystyrene tissue culture bottles (Corning, Medfield, MA, USA) using endotoxin-free, tissue culture-grade water (Sigma Chemical Co., Cat. No. W3500). Media were filter-sterilized through $0.22 \mu \mathrm{m}$ Millipore filters (Millipore Corp., Bedford, MA, USA) in Nalgene reusable filter holders (Cat. No. 300-4000). Media were gassed with $5 \% \mathrm{CO}_{2} / 5 \% \mathrm{O}_{2} / 90 \% \mathrm{~N}_{2}$ and stored at $4^{\circ} \mathrm{C}$. Fresh media were prepared every 2 weeks. Osmolarity of all media was tested by freezing point depression and ranged from 274 to 295 mosmol which is within the acceptable range of osmolarities determined by Brinster (1965b) for development of 2-cell embryos.

Culture procedures. Media were pipetted in $50 \mu \mathrm{l}$ drops into Falcon 60 -mm Petri dishes (Falcon Cat. No. 1007 , Beckton Dickinson, Lincoln Park, NJ, USA) and overlaid with medium-washed Fisher 121 paraffin oil. Media drops in 
Table 1. Media formulation

\begin{tabular}{|c|c|c|c|c|c|}
\hline \multirow[b]{2}{*}{ Component $\dagger$} & \multicolumn{5}{|c|}{ Concentration (mM) } \\
\hline & $\begin{array}{l}\text { Modified } \\
\text { M16 }\end{array}$ & $\begin{array}{l}\text { Modified } \\
\text { WM }\end{array}$ & EBSS + EDTA* & $\begin{array}{l}\text { Modified } \\
\text { BMOC-2 }\end{array}$ & $\mathrm{CZB} \S$ \\
\hline $\mathrm{NaCl}$ & $94 \cdot 62$ & $109 \cdot 51$ & 117.00 & 88.98 & $81 \cdot 62$ \\
\hline $\mathrm{KCl}$ & 4.83 & $4 \cdot 83$ & $5 \cdot 40$ & $4 \cdot 83$ & $4 \cdot 83$ \\
\hline $\mathrm{KH}_{2} \mathrm{PO}_{4}$ & $1 \cdot 18$ & $1 \cdot 18$ & - & $1 \cdot 18$ & $1 \cdot 18$ \\
\hline $\mathrm{MgSO}_{4} \cdot 7 \mathrm{H}_{2} \mathrm{O}$ & $1 \cdot 18$ & $1 \cdot 18$ & 0.80 & $1 \cdot 18$ & $1 \cdot 18$ \\
\hline $\mathrm{NaHCO}_{3}$ & $25 \cdot 00$ & $22 \cdot 62$ & $22 \cdot 00$ & $25 \cdot 12$ & $25 \cdot 12$ \\
\hline $\mathrm{NaH}_{2} \mathrm{PO}_{4} \cdot \mathrm{H}_{2} \mathrm{O}$ & - & - & 1.00 & - & - \\
\hline $\mathrm{CaCl}_{2} \cdot 2 \mathrm{H}_{2} \mathrm{O}$ & $1 \cdot 70$ & - & 1.80 & $1 \cdot 70$ & 1.70 \\
\hline D-Glucose & $5 \cdot 55$ & $5 \cdot 55$ & $5 \cdot 55$ & 5.55 & - \\
\hline Sodium lactate $\neq$ & $22 \cdot 00$ & - & $26 \cdot 17$ & $29 \cdot 90$ & $31 \cdot 30$ \\
\hline Calcium lactate & - & $4 \cdot 86$ & $0 \cdot 17$ & - & - \\
\hline Sodium pyruvate & 0.55 & 0.27 & $0 \cdot 30$ & 0.27 & 0.27 \\
\hline EDTA (disodium salt) & - & - & 0.01 & $0 \cdot 11$ & $0 \cdot 11$ \\
\hline Glutamine & - & - & - & - & $1 \cdot 00$ \\
\hline BSA $(\mathrm{mg} / \mathrm{ml})$ & $4 \cdot 00$ & 3.00 & $4 \cdot 00$ & $5 \cdot 00$ & $5 \cdot 00$ \\
\hline Sodium penicillin $\mathrm{G}(\mathrm{U} / \mathrm{ml})$ & $100 \cdot 00$ & $\begin{array}{c}121 \cdot 00 \\
\text { (K salt) }\end{array}$ & 133.00 & $100 \cdot 00$ & $100 \cdot 00$ \\
\hline Streptomycin $(\mathrm{mg} / / \mathrm{ml})$ & 0.50 & $0 \cdot 50$ & - & $0 \cdot 70$ & 0.70 \\
\hline Phenol red $(\mathrm{mg} / \mathrm{ml})$ & - & - & 0.01 & - & - \\
\hline Lactate/pyruvate ratio & $40 \cdot 00$ & 17.89 & $87 \cdot 70$ & $110 \cdot 74$ & 115.92 \\
\hline
\end{tabular}

${ }^{*}$ EBSS was purchased from GIBCO (Cat. No. 450-1100 Grand Island, NY, USA) and supplemented with sodium bicarbonate, sodium lactate, calcium lactate, EDTA, pyruvate and BSA (Dr Ann Kiessling, personal communication).

$\nmid \mathrm{KCl}$ and $\mathrm{NaHCO}_{3}$ were Mallinckrodt Chemicals (Mallinckrodt Inc., Paris, KY, USA). BSA was obtained from Armour Pharmaceutical Co. (Kankakee, IL, USA). All other components were obtained from Sigma Chemical Co. (St Louis, MO, USA).

$\mp$ Concentration based on using a $60 \%$ solution of DL-sodium lactate on a w/w basis (Sigma Chemical Co., St Louis, MO, USA).

§CZB with glucose contains $5.55 \mathrm{~mm}$-glucose.

culture plates were equilibrated with $5 \% \mathrm{CO}_{2} / 5 \% \mathrm{O}_{2} / 90 \% \mathrm{~N}_{2}$ in a sealed chamber (Billips Rothenberg, Del Mar, CA, USA) at $37^{\circ} \mathrm{C}$ for $4-5 \mathrm{~h}$ before use. One-cell embryos were removed from the holding dish and washed through one drop of test medium into a final culture drop. A culture drop of $50 \mu \mathrm{l}$ contained a maximum of 25 embryos. Cultures were incubated in sealed culture chambers gassed with $5 \% \mathrm{CO}_{2} / 5 \% \mathrm{O}_{2} / 90 \% \mathrm{~N}_{2}$ at $37^{\circ} \mathrm{C}$. In experiments in which washing was required, embryos were removed from the culture chamber at 24 (Day 2), 48 (Day 3) or 72 (Day 4) h of culture and transferred through a wash drop of fresh medium into a culture drop of fresh medium as indicated and returned to the culture chamber. In some experiments, glucose (from a $100 \mathrm{mg} / \mathrm{ml} \mathrm{stock}$ ) was injected directly into the original culture drop at $48 \mathrm{~h}$ of culture (Day 3). Cultures were terminated at $96 \mathrm{~h}$ (Day 4, 121-123 h after hCG). Embryos were scored for developmental stage and abnormalities on Days 4 and 5 and were then fixed on Day 5 in $4 \%$ paraformaldehyde in PBS, washed into PBS and stained with Hoechst $33258(10 \mu \mathrm{g} / \mathrm{ml}$ in HBSS + BSA, Cat. No. B2883 Sigma Chemical Co., St Louis, MO, USA) to label the nuclei fluorescently. Nuclei were counted on a Nikon Diaphot inverted phase-contrast microscope with fluorescence attachment under u.v. illumination. Average nuclei per morula and per blastocyst were calculated. Nuclei of abnormal embryos were not counted as many had undergone significant degeneration.

Statistical analysis. To control for variation in development between animals, embryos from each animal were randomly distributed among all culture samples in a given experiment unless otherwise noted. Each experimental protocol represents a minimum of 2 replicates performed on different days or by different people. For all experiments, a complete set of samples was run simultaneously (e.g. for each matrix replicate all 4 samples were run at the same time). Statistical analysis of experiments was performed with an NCSS software package (Number Cruncher Statistical System, NCSS, Kaysville, UT, USA) using a standard arcsin transformation (Sokal \& Rohlf, 1981) of the data and analysis of variance or Student's $t$ test. Statistical analysis of morula and blastocyst nuclear counts was performed on the non-transformed counts using Student's $t$ test. 


\section{Results}

In initial experiments, when 1-cell $\mathrm{CF} 1 \times \mathrm{B} 6 \mathrm{SJF} 1 / \mathrm{J}$ embryos were cultured in Medium M16, WM or EBSS with EDTA for $96 \mathrm{~h}$ (Table 2), embryo development was generally blocked at the 2-cell stage on Day 4 with some proceeding further but not beyond the 8-cell stage. Other preliminary experiments (data not shown) indicated that addition of $1 \mathrm{~mm}$-glutamine to or the elimination of glucose from Medium M16 would allow 7-34\% of 1-cell embryos to develop beyond 2-cells and $1-2 \%$ to morula or blastocyst. Furthermore, the addition of EDTA alone to Medium M16 was ineffective in overcoming the 2 -cell block to in-vitro development in these embryos.

Table 2. Culture of 1-cell embryos in various media for 5 days

\begin{tabular}{|c|c|c|c|c|c|c|c|c|c|c|c|c|}
\hline \multirow[b]{2}{*}{ Sample } & \multicolumn{5}{|c|}{ Day 4} & \multicolumn{7}{|c|}{ Day 5} \\
\hline & Total & $\% 2 \mathrm{C}$ & $\% 3-8 \mathrm{C}$ & $\% \mathrm{M}$ & $\%$ Abn & Total & $\% 2 \mathrm{C}$ & $\% 3-8 \mathrm{C}$ & $\% \mathrm{M}$ & $\% \mathrm{Bl}$ & $\% \mathrm{M}+\mathrm{Bl}$ & $\%$ Abn \\
\hline M16 & 50 & 84 & 2 & 0 & 14 & 100 & 44 & 3 & 0 & 0 & 0 & 53 \\
\hline WM & 75 & 79 & 4 & 0 & 18 & 75 & 37 & 0 & 0 & 0 & 0 & 63 \\
\hline \multicolumn{13}{|l|}{$\mathrm{EBSS}+$} \\
\hline EDTA* & 174 & 57 & 0 & 0 & 35 & 160 & 18 & 0 & 0 & 0 & 0 & 76 \\
\hline $\mathrm{CZB}+\mathrm{glc}$ & 100 & 41 & 16 & 18 & 25 & 100 & 8 & 4 & 3 & 8 & 11 & 77 \\
\hline CZB & 949 & 4 & 20 & 63 & 13 & 846 & 1 & 4 & 6 & 3 & 9 & 86 \\
\hline
\end{tabular}

Abbreviations: Total $=$ total no. of embryos tested; $2 \mathrm{C}=2$-cells; $3-8 \mathrm{C}=3$-8-cells; $\mathrm{M}=$ morula; $\mathrm{Bl}=$ blastocysts; Abn = abnormal; glc $=$ glucose.

Experiments were not always scored on both Day 4 and Day 5, therefore totals may be different on the 2 days for a given sample.

* $8 \%$ of embryos cultured in EBSS and EDTA remained as 1-cells on Day 4 and $6 \%$ were still 1-cells on Day 5.

These preliminary results, together with similar published findings for the hamster (Bavister et al., 1983; Carney \& Bavister, 1987; Schini \& Bavister, 1988; Seshagiri \& Bavister, 1989), resulted in the development of the medium designated CZB (Table 1). Compared with Medium M16 or modified BMOC-2 media, CZB medium has a higher lactate/pyruvate ratio, which may be crucial for the development of 1-cell embryos through the 2-cell stage (Cross \& Brinster, 1973), lacks glucose, contains 0.1 mM-EDTA (Dr Karl Ebert, personal communication) and $1 \mathrm{~mm}$-glutamine.

\section{Effect of different media on embryo culture}

Experiments using CZB medium (without glucose) demonstrated that development of 1-cell CF-1 $\times$ B6SJLF1/J embryos through the 2-cell stage to the morula stage was significantly improved over other media tested on these embryos (Table 2). The addition of glucose to Medium CZB was inhibitory to development with only $18 \%$ developing to the morula stage by Day 4 . By Day 5, however, $77 \%$ and $86 \%$ of embryos cultured in Medium CZB with or without glucose had become abnormal (Table 2).

\section{Effect of washing variations on embryo culture}

The successful development of CF-1 $\times$ B6SJLF1/J 1-cell embryos through the 2-cell stage in Medium CZB but the inability of this medium to support the transition from morula to blastocyst led us to question whether there was a stage-specific requirement for glucose during embryo culture even though continuous exposure to glucose was inhibitory to development. To define a window for potential glucose enhancement of development, 1-cell embryos cultured in Medium CZB were washed into Medium CZB + glucose, and in some cases back into Medium CZB, at various times during the culture period. As before, Medium CZB for the duration of the culture period allowed 
$72 \%$ of embryos to develop to the morula stage on Day 4 but only $11 \%$ proceeded to the morula or blastocyst stage on Day 5 (Table 3). Washing into Medium CZB + glucose on Day 2, with or without a wash back into Medium CZB on Days 3 or 4 , did not increase the percentage of embryos reaching the morula or blastocyst stage on Day 5. However, a wash into Medium CZB + glucose on Day 3 or injection of glucose directly into the Medium CZB culture drop was sufficient to allow $47 \%$ and $70 \%$, respectively, of embryos to develop to morula or blastocysts (Day 5). If embryos were washed into Medium CZB + glucose on Day 3 and then washed back into Medium CZB on Day 4, 63\% of embryos developed to morula or blastocysts on Day 5. Embryos washed from Medium CZB into Medium CZB + glucose on Day 4 did not form any blastocysts on Day 5. Treatments in which embryos were exposed to glucose on Day 3 did not differ significantly from one another. However, glucose exposure of any kind on Day 3 caused significant improvements in embryo development (by Student's $t$ test) compared with no wash, wash on Day 2 with or without a wash back into Medium CZB on Day 3 or Day 4, or wash on Day 4. Nuclear counts of embryos which developed to the morula stage were significantly reduced in the samples which were washed into glucose on Days $2(9 \cdot 0 \pm 1 \cdot 0,10 \cdot 2 \pm 3 \cdot 4)$ or $4(10 \cdot 3 \pm 1 \cdot 7)$ compared with Day $3(16 \cdot 2 \pm 1 \cdot 1)$ $(P<0.05)$. Any embryos which developed to the blastocyst stage regardless of day of glucose exposure did not differ significantly from one another in cell number. These results define a relatively narrow window during which glucose is required by these embryos, beginning at the 3-4-cell stage (Day 3, afternoon) and extending for a maximum of $24 \mathrm{~h}$ to the early morula stage (Day 4 afternoon). An exposure to glucose at too early (Day 2, 2-cells) or too late (Day 4, early morula) a time was ineffective in enhancing embryo development.

Following the definition of an optimum time for washing into glucose-containing medium, the type of medium which could be utilized for washing was investigated. Embryos were cultured from the 1-cell stage in Medium CZB and at $48 \mathrm{~h}$ were either not washed or washed into Medium CZB, Medium CZB + glucose or Medium M16. Both Medium CZB + glucose and Medium M16 were effective at promoting significant development to the blastocyst stage with $49 \%$ morula or blastocysts on Day 5 (Table 4) compared to no wash or Medium CZB. The average number of nuclei per embryo for morulae was $16 \cdot 1 \pm 1 \cdot 34(n=15)$ for Medium CZB + glucose and 14.5 $\pm 1 \cdot 38(n=6)$ for Medium M16 and for blastocysts was 34.9 $\pm 1.61(n=30)$ for Medium CZB + glucose and $35.0 \pm 1.75(n=41)$ for Medium M16 (not significantly different). Both the unwashed condition and washing into Medium CZB without glucose, although permitting some development to the morula stage on Day 4, were ineffective at promoting the transition from morula to blastocyst on Day 5 (Table 4).

\section{Timing of glutamine effectiveness}

Since washing into Medium M16 (no glutamine) at $48 \mathrm{~h}$ was as effective in promoting the morula to blastocyst transition as washing into Medium CZB + glucose, the question of when glutamine exerts its effect was investigated. One-cell embryos were cultured for $48 \mathrm{~h}$ in Medium CZB with or without glutamine and washed into Medium CZB + glucose with or without glutamine as described in Table 5. Glutamine was beneficial to embryo development during the first $48 \mathrm{~h}$ of culture. Embryos cultured in Medium CZB, regardless of the presence or absence of glutamine in the Medium CZB + glucose wash, developed to the morula stage on Day 4 and to the morula or blastocyst stage on Day 5 (Table 5). Of the embryos cultured in the absence of glutamine for the first $48 \mathrm{~h}$, regardless of the presence or absence of glutamine in the wash, fewer reached the morula stage on Day 4 and only approximately $30 \%$ developed to the morula or blastocyst stage on Day 5 (Table 5). By analysis of variance, the presence of glutamine in the medium before washing on Day 3 caused a significant positive effect on development while the presence of glutamine in the medium after washing on Day 3 caused no effect on development. Medium CZB cultures with glutamine, washed on Day 3 into Medium CZB + glucose with or without glutamine, were not significantly different from one another by (Student's $t$ test). Likewise, cultures in Medium CZB without 


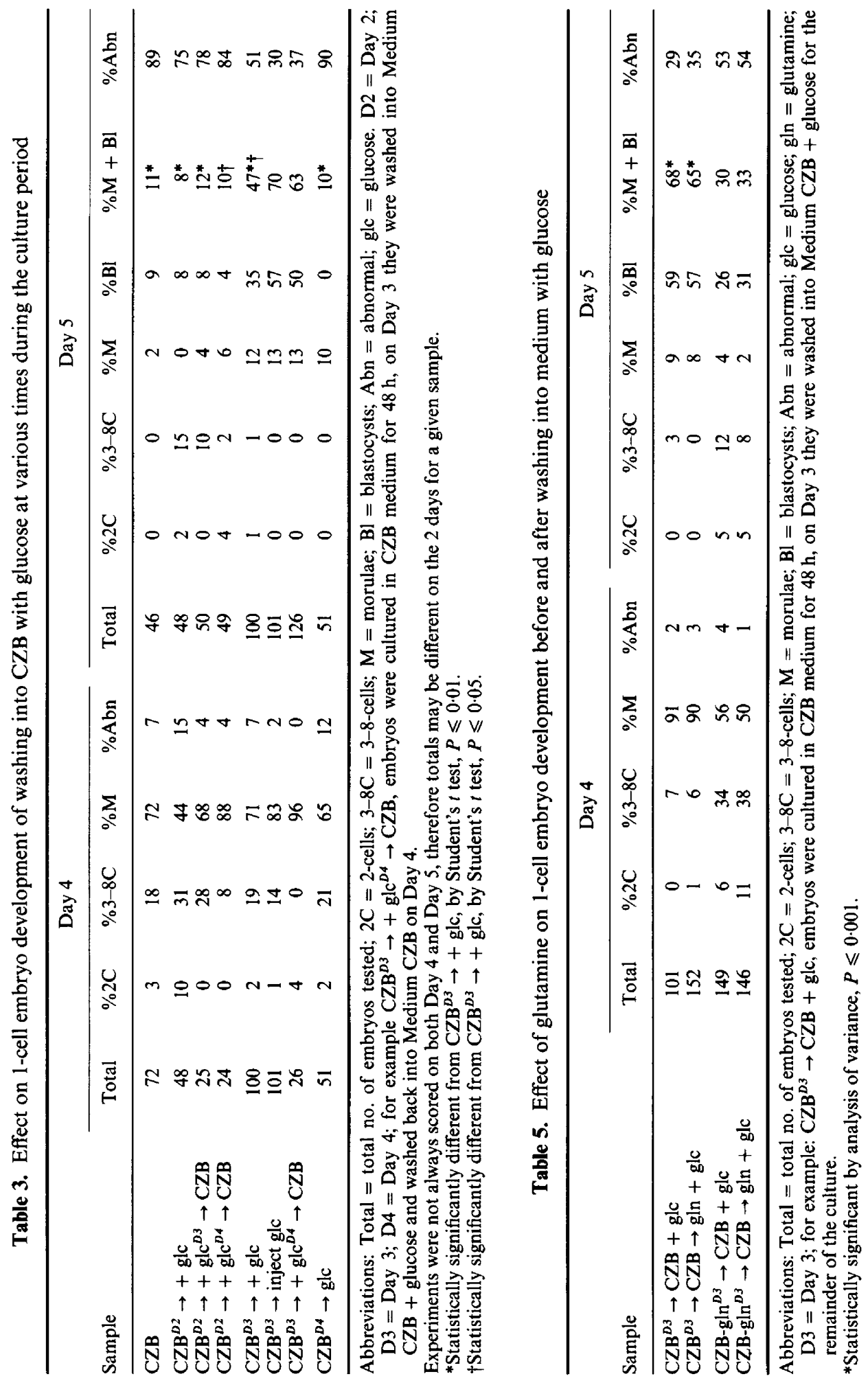


Table 4. Effect of washing embryos from CZB into various media at $48 \mathrm{~h}$ of culture

\begin{tabular}{|c|c|c|c|c|c|c|c|c|c|c|c|c|}
\hline \multirow[b]{2}{*}{ Sample } & \multicolumn{5}{|c|}{ Day 4} & \multicolumn{7}{|c|}{ Day 5} \\
\hline & Total & $\% 2 \mathrm{C}$ & $\% 3-8 \mathrm{C}$ & $\% \mathrm{M}$ & $\%$ Abn & Total & $\% 2 \mathrm{C}$ & $\% 3-8 \mathrm{C}$ & $\% \mathrm{M}$ & $\% \mathrm{Bl}$ & $\% \mathbf{M}+\mathbf{B} 1$ & $\%$ Abn \\
\hline No wash & 50 & 6 & 22 & 58 & 14 & 75 & 1 & 1 & 0 & 1 & $1^{*} \dagger$ & 97 \\
\hline CZB & 75 & 9 & 5 & 53 & 32 & 99 & 5 & 1 & 10 & 5 & $15 * \dagger$ & 79 \\
\hline $\mathrm{CZB}+\mathrm{glc}$ & 75 & 3 & 11 & 80 & 7 & 99 & 2 & 2 & 18 & 31 & $49^{*}$ & 46 \\
\hline M16 & 76 & 1 & 12 & 86 & 3 & 102 & l & 0 & 6 & 43 & $49 \dagger$ & 50 \\
\hline
\end{tabular}

Abbreviations: Total $=$ total no. of embryos tested; $2 \mathrm{C}=2$-cells; $3-8 \mathrm{C}=3-8$-cells; $\mathrm{M}=$ morulae; $\mathrm{Bl}=$ blastocysts; $\mathrm{Abn}=$ abnormal; glc $=$ glucose.

Experiments were not always scored on both Day 4 and Day 5, therefore totals may be different on the 2 days for a given sample.

*Statistically significantly different from CZB + glc, by Student's $t$ test, $P \leqslant 0.001$.

† Statistically significantly different from M16, by Student's $t$ test, $P \leqslant 0 \cdot 01$.

glutamine, regardless of wash, were not significantly different from each other. Embryos which proceeded to the morula or blastocyst stage in any treatment did not differ significantly from each other in total numbers of nuclei.

\section{Effect of glutamine and glucose on embryo culture}

To determine the relative effects of glucose and glutamine on development, a $2^{2}$ factorial experiment was performed (Table 6). One-cell embryos were cultured in Medium CZB with or without glucose and/or glutamine for $48 \mathrm{~h}$ and were then washed into identical medium containing glucose for the remainder of the culture period. Glucose, although required after Day 3, was detrimental to embryo development during the first $48 \mathrm{~h}$ of culture (Table 6). Glutamine enhanced the rate of morula and blastocyst formation on Day 5, both in the presence and absence of glucose. Optimal development occurred in Medium CZB which contained $1 \mathrm{~mm}$-glutamine but no glucose for the first $48 \mathrm{~h}$. By analysis of variance, the removal of glucose and the addition of glutamine both caused independently significant improvements in embryo development. There was no significant interaction detected between glucose removal and glutamine addition by this analysis.

Table 6. Effect of glutamine and glucose on 1-cell embryo development

\begin{tabular}{|c|c|c|c|c|c|c|c|c|c|c|c|c|}
\hline \multicolumn{2}{|c|}{ Sample } & \multicolumn{5}{|c|}{ Day 4} & \multicolumn{6}{|c|}{ Day 5} \\
\hline Gln & Glc & Total & $\% 2 \mathrm{C}$ & $\% 3-8 \mathrm{C}$ & $\% \mathrm{M}$ & $\% \mathrm{Abn}$ & $\% 2 \mathrm{C}$ & $\% 3-8 \mathrm{C}$ & $\% \mathbf{M}$ & $\% \mathrm{Bl}$ & $\% \mathbf{M}+\mathbf{B l}$ & $\%$ Abn \\
\hline- & + & 52 & 71 & 21 & 0 & 8 & 34 & 4 & 0 & 0 & 0 & 62 \\
\hline+ & + & 49 & 18 & 43 & 39 & 0 & 6 & 8 & 2 & 8 & $10 \dagger$ & 75 \\
\hline - & - & 47 & 11 & 36 & 53 & 0 & 8 & 2 & 2 & 28 & $30^{*}$ & 60 \\
\hline+ & - & 50 & 0 & 10 & 90 & 0 & 0 & 0 & 6 & 52 & $58 * \dagger$ & 42 \\
\hline
\end{tabular}

Abbreviations: Total $=$ total no. of embryos tested; $2 \mathrm{C}=2$-cells; $3-8 \mathrm{C}=3-8$-cells; $\mathrm{M}=$ morulae; $\mathrm{Bl}=$ blastocysts; $\mathrm{Abn}=\mathrm{abnormal} ;$ glc $=$ glucose; gln $=$ glutamine. All samples were washed on Day 3 into the same variant but with glucose.

* Removal of glucose was statistically significant by analysis of variance, $P=0.007$.

$\uparrow$ Addition of glutamine was statistically significant by analysis of variance, $P=0.05$.

\section{Discussion}

In the present study, the 2-cell block to in-vitro development of 1-cell CF-1 $1 \times$ B6SJLF1/J embryos has been overcome by optimizing the culture conditions and the medium used for culture. These embryos were shown to block at the 2-cell stage in Medium M16, WM and EBSS with EDTA. 
Continuous culture of 1-cell embryos in CZB medium which has a lactate/pyruvate ratio of 116 , contains $1 \mathrm{~mm}$-glutamine, $0.1 \mathrm{~mm}$-EDTA and lacks glucose resulted in the development of $83 \%$ of embryos beyond the 2-cell stage, but only $9 \%$ of these embryos formed blastocysts. A protocol that involved culture of 1-cell embryos for $48 \mathrm{~h}$ in CZB medium followed by a transfer into Medium $\mathrm{CZB}+$ glucose for the remaining $48 \mathrm{~h}$ of the culture period led to an average of $58 \%$ of all 1 -cell embryos developing to the morula or blastocyst stage. These results have been confirmed for 1-cell embryos from CF-1 donors by Dr Richard Schultz and Dr Joanne Conover, University of Pennsylvania (using a wash into WM at $48 \mathrm{~h}$ ) and Dr John Biggers, Dr Joel Lawitts and Susan Palmieri, Harvard Medical School (using a wash into Medium M16 at $48 \mathrm{~h}$ ), and for 1-cell embryos from random bred Swiss mice by Dr Robert Petters, Dr Anthony Archibong, Rebecca Krisher and Betsy Houston, North Carolina State University. CZB medium for these experiments was freshly prepared at each location and appears to be reproducible in other laboratories.

The removal of glucose from the medium during the first $48 \mathrm{~h}$ of culture led to a significant improvement in embryo development beyond the 1-cell stage. Brinster (1965c) observed a slightly detrimental effect of glucose on development of 2-cell random-bred Swiss mouse embryos. In the hamster, Schini \& Bavister (1988) demonstrated that glucose (in the presence of phosphate) contributes to the hamster 2 -cell block (only $2.7 \%$ beyond 2 -cells). Elimination of glucose from their medium resulted in development of $27 \%$ of embryos beyond the 2 -cell stage. There is also an 8-cell block to in-vitro development in the hamster. Seshagiri \& Bavister (1989) have shown that the development of 8-cell embryos to blastocysts was depressed to $50 \%$ in the presence of $5.0 \mathrm{~mm}$-glucose compared with $88 \%$ in the same medium lacking glucose.

The glucose inhibition of 1-cell mouse embryo development is confined to the first $48 \mathrm{~h}$ of culture. Washing embryos before this time into glucose containing medium is detrimental to blastocyst formation. After $48 \mathrm{~h}$ in the absence of glucose, exposure of embryos to glucose for a maximum of $24 \mathrm{~h}$ promoted development to the blastocyst stage. Continuous exposure beyond $24 \mathrm{~h}$, although not detrimental, is not required for blastocyst formation. Development from the 8-cell to the blastocyst stage in the absence of glucose has been independently observed previously by Brinster (1965c) and more recently by F. Manejwala \& R. Schultz (personal communication). After $72 \mathrm{~h}$ of culture from the 1-cell stage in the absence of glucose, embryos cannot be rescued by exposure to glucose-containing medium.

In the present study, glutamine promoted significant improvement in development from the 1-cell stage to the blastocyst stage. Its primary influence is exerted during the first $48 \mathrm{~h}$ of culture. Glutamine is accumulated by the 1-2-cell mouse embryo (Brinster, 1971) to a greater extent than at least 10 other amino acids. Glutamine has been implicated as an important amino acid in the maturation and development of hamster (Gwatkin \& Haidri, 1973) and rabbit (Bae \& Foote, 1975) oocytes and in the development of hamster embryos beyond the 2-cell block (Schini \& Bavister, 1988) and the 8-cell block (Bavister et al., 1983; Carney \& Bavister, 1987). The role of glutamine in the development of the embryo is not clear although in cultured somatic cells glutamine can be utilized as an energy substrate in place of glucose (Eagle et al., 1955; Reitzer et al., 1979). Zielke et al. (1978) described a reciprocal regulation of utilization between glucose and glutamine in human diploid fibroblasts. A similar role for glutamine could be postulated for embryos in culture with the presence or absence of glucose regulating the use of glutamine as an energy substrate (Table 6). It is possible that blocking mouse embryos have the ability to metabolize lactate and pyruvate, but do not generate sufficient energy in this way to develop in vitro. The addition of glutamine and the removal of glucose may allow increased glutamine metabolism to supply the additional energy substrates required for development of the 1-cell mouse embryo beyond the 2-cell stage. Other mechanisms however, are possible.

These culture experiments were initiated at the Worcester Foundation in the fall of 1987 and at that time, continuous culture in CZB medium without washing into glucose promoted development of $83 \%$ of embryos beyond the 2-cell stage with $58 \%$ developing to blastocyst. This protocol worked effectively until April of 1988 at which time a wash into glucose at $48 \mathrm{~h}$ became essential. 
The reasons for this change in the requirement for glucose are unclear. Experiments are in progress to determine whether this change is due to some seasonal influence on embryos or to uncontrolled variations in culture medium ingredients, particularly the water.

In summary, development in vitro beyond the 2-cell stage has been achieved for 1-cell embryos from CF-1 females $\times$ B6SJLF1/J males. That these embryos still block in selected media even when mated to an F1 non-blocking strain of males supports the maternal origin of the 2-cell block as described by Muggleton-Harris et al. (1982), Goddard \& Pratt (1983) and Pratt \& MuggletonHarris (1988). Changes in the medium composition which allowed development beyond the 2-cell stage suggest that glutamine in addition to lactate and pyruvate may be a required energy substrate for in-vitro development of the embryo in some strains of mice, and that glucose is inhibitory during the first two cleavage divisions in vitro.

We thank Dr Robert Petters, Dr Richard Schultz and Dr John Biggers for testing CZB medium and the culture protocol in their laboratories; Dr John Biggers and Dr Richard Tasca for advice and critically reviewing this manuscript; and Dr Karl Ebert and Dr Ann Kiessling for helpful discussion. This work was done as part of the National Cooperative Program on Non-Human In Vitro Fertilization and Preimplantation Development and was funded by the National Institute of Child Health and Human Development, NIH, through cooperative agreement HD21942.

\section{References}

Abramczuk, J. Solter, D. \& Koprowski, H. (1977) The beneficial effect of EDTA on development of mouse one-cell embryos in chemically defined medium. Devl Biol. 61, 378-383.

Bae, I.H. \& Foote, R.H. (1975) Carbohydrate and amino acid requirements and ammonia production of rabbit follicular oocytes matured in vitro. Expl Cell Res. 91, $113-118$.

Bavister, B.D., Leibfried, M. \& Leiberman, G. (1983) Development of preimplantation embryos of the golden hamster in a defined culture medium. Biol. Reprod. 28, 235-247.

Biggers, J.D., Moore, B.D. \& Whittingham, D.G. (1965) Development of mouse embryos in vivo after cultivation from two-cell ova to blastocysts in vitro. Nature, Lond. 206, 734735.

Biggers, J.D., Whittingham, D.G. \& Donahue, R.P. (1967) The pattern of energy metabolism in the mouse oocyte and zygote. Proc. natn. Acad. Sci. USA 58, 560-567.

Brinster, R.L. (1963) A method for in vitro cultivation of mouse ova from two-cell to blastocyst. Expl Cell Res. 32, 205-208.

Brinster, R.L. (1965a) Studies on the development of mouse embryos in vitro. IV. Interactions of energy sources. J. Reprod. Fert. 10, 227-240.

Brinster, R.L. (1965b) Studies on the development of mouse embryos in vitro. I. Effect of osmolarity and hydrogen ion concentration. J. exp. Zool. 158, 49-58.

Brinster, R.L. (1965c) Studies on the development of mouse embryos in vitro. II. The effect of energy source. J. exp. Zool. 158, 59-68.

Brinster, R.L. (1971) Uptake and incorporation of amino acids by the preimplantation mouse embryo. $J$. Reprod. Fert. 27, 329-338.

Carney, E.W. \& Bavister, B.D. (1987) Stimulatory and inhibitory effects of amino acids on development of hamster eight-cell embryos in vitro. J. in Vitro Fert. Embryo Transfer 4, 162-167.

Cross, P.C. \& Brinster, R.L. (1973) The sensitivity of one-cell mouse embryos to pyruvate and lactate. Expl Cell Res. 77, 57-62.

Dandekar, P.V. \& Glass, R.H. (1987) Development of mouse embryos in vitro is affected by strain and culture medium. Gamete Res. 17, 279-285.

Eagle, H., Oyama, V.I., Levy, M., Horton, C.L. \& Fleischman, R. (1955) The growth response of mammalian cells in tissue culture to $\mathrm{L}$-glutamine and $\mathrm{L}$ glutamic acid. J. biol. Chem. 218, 607-616.

Ebert, K.M. \& Brinster, R.L. (1983) Rabbit $\alpha$-globin messenger RNA translation by the mouse ovum. $J$. Embryol. exp. Morph. 74, 159-168.

Goddard, M.J. \& Pratt, H.P.M. (1983) Control of events during early cleavage of the mouse embryo: an analysis of the '2-cell block'. J. Embryol. exp. Morph. 73, 111-133.

Gwatkin, R.B.L. \& Haidri, A.A. (1973) Requirements for the maturation of hamster oocytes in vitro. Expl Cell Res. 76, 1-7.

Hoppe, P.C. (1985) Technique of fertilization in vitro. In Reproductive Toxicology, pp. 191-199. Ed. R. L. Dixon. Raven Press, New York.

Kaufman, M.H. \& Sachs, L. (1976) Complete preimplantation development in culture of parthenogenetic mouse embryos. J. Embryol. exp. Morph. 35, 179-190.

Loutradis, D., John, D. \& Kiessling, A.A. (1987) Hypoxanthine causes a 2-cell block in random-bred mouse embryos. Biol. Reprod. 37, 311-316.

Muggleton-Harris, A., Whittingham, D.G. \& Wilson, L. (1982) Cytoplasmic control of preimplantation development in vitro in the mouse. Nature, Lond. 229, 460-462.

Pratt, H.P.M. \& Muggleton-Harris, A.L. (1988) Cycling cytoplasmic factors that promote mitosis in the 
cultured 2-cell mouse embryo. Development 104, $115-120$.

Quinn, P. \& Harlow, G.M. (1978) The effect of oxygen on the development of preimplantation mouse embryos in vitro. J. exp. Zool. 206, 73-80.

Reitzer, L.J., Wice, B.M. \& Kennell, D. (1979) Evidence that glutamine, not sugar, is the major energy source for cultured HeLa cells. J. biol. Chem. 254, 2669-2676.

Schini, S.A. \& Bavister, B.D. (1988) Two-cell block to development of cultured hamster embryos is caused by phosphate and glucose. Biol. Reprod. 39, 1183-1192.

Schumacher, A. \& Fischer, B. (1988) Influence of visible light and room temperature on cell proliferation in preimplantation rabbit embryos. J. Reprod. Fert. 84, 197-204.

Seshagiri, P.B. \& Bavister, B.D. (1989) Glucose inhibits development of hamster 8-cell embryos in vitro. Biol. Reprod. 40, 599-606.
Sokal, R.R. \& Rohlf, F.J. (1981) Biometry, pp. 427-428. W.H. Freeman and Co., New York.

Whitten, W.K. (1957) Culture of tubal ova. Nature, Lond. 179, 1081-1082.

Whitten, W.K. \& Biggers, J.D. (1968) Complete development in vitro of the preimplantation stages of the mouse in a simple chemically defined medium. $J$. Reprod. Fert. 17, 399. 401.

Whittingham, D.G. (1971) Culture of mouse ova. $J$. Reprod. Fert., Suppl. 14, 7-21.

Whittingham, D.G. \& Biggers, J.D. (1967) Fallopian tube and early cleavage in the mouse. Nature, Lond. 213, 942.

Zielke, H.R., Ozand, P.T., Tildon, J.T., Sevdalian, D.A. \& Cornblath, M. (1978) Reciprocal regulation of glucose and glutamine utilization by cultured human diploid fibroblasts. J. Cell Physiol. 95, 41-48.

Received 21 November 1988 